\title{
Development JEJAKATUA Using Auto-Stitching as a Campus Virtual Tour to Support Digital Promotion Media
}

\author{
Tri Lathif Mardi Suryanto*, Nur Cahyo Wibowo \\ Information System, Faculty of Computer Science, Universitas Pembangunan Nasional "Veteran" \\ Jawa Timur
}

*Corresponding author:

E-mail: trilathif.si@upnjatim.ac.id

\begin{abstract}
In the current millennial era, the digitalization of promotions offers abundant potential so that each agency is competing to attract public attention through the development of promotional digitization. East Java "Veteran" National Development University has the same opportunity to compete in providing the best digital information and promotions. As for some urgency to immediately build a campus network, it needs to be developed, prospective new students, prospective work partners, or colleagues who come from outside the city, outside the region, or even abroad, a distance appropriate to the cost becomes an obstacle to realizing the journey to campus, and the need provide real experiences and deeper impressions for the stakeholders to see the contents of the Campus. So, this study aims to build a Virtual Campus Exploration application (Jejakatua) as a Media Promotion Era at the "Veteran" National Development University of East Java. The result of this research has succeeded in building JEJAKATUA and can facilitate the limitations of distance, space, time, and costs for all Campus stakeholders in a more real, realistic, and interactive virtual form.
\end{abstract}

Keywords: Virtual tour, virtual campus, digital promotion, jejakatua.

\section{Introduction}

Promotion is an attempt to notify or offer a product or service to attract potential customers to buy or consume it. With the promotion of producers or distributors expecting an increase in sales figures. (wikipedia.com). However, with the use of technology in the Millennial Era, promotional media has more abundant use, strategies, methods, and applications. Digitization of promotions in the Millennial Era occurs not only in non-Government Agencies but also in Government Institutions, in the end, each Institution competes to provide information that attracts broad public interest.

As the New State University (PTNB) of the Universitas Pembangunan Nasional "Veteran" Jawa Timur which was later called (UPN "Veteran" Jatim) had the same opportunity to compete to provide the best and more competitive digital information and promotion services. The influence of service quality and customer value can influence the image of the Institution (Hendrayana, 2014). UPN "Veteran" Jatim must be able to provide public services to prospective students to prospective domestic and foreign cooperation partners. But digital promotion at UPN "Veteran" Jatim is still limited to the application of the official website of the Institution, while many prospective students and prospective Campus partners who need information are more than static information.

So, this study formulates the urgency of the implementation of digital promotion at UPN "Veteran" Jatim, while the urgency of research is: (1) Campus networks need to develop starting from Regional, National, and even International. (2) Prospective new students, prospective partners, or colleagues from outside the city, outside the region, or even abroad certainly have a curiosity

\section{How to cite:}

Suryanto, T. L. M., \& Wibowo, N. C. (2021). Development JEJAKATUA using auto-stitching as a campus virtual tour to support digital promotion media. $5^{\text {th }}$ International Seminar of Research Month 2020. NST Proceedings. pages 64-70. doi: $10.11594 /$ nstp.2021.0910 
about the description of the campus to be chosen. (3) The distance that is in line with costs is an obstacle to realizing the journey to the Campus. (4) Virtual Campus Tour is a solution in the millennial era like now to provide a real experience and a deeper impression for these parties than just reading static data and photos on the official UPN "Veteran" Jatim website.

The challenge of providing good service is the goal of State Universities. In the end, all competed at the prime service point. Campus service quality performance is determined by the quality of service provided to stakeholders. Quality of service within the Campus is determined by the extent to which people's needs and expectations can be met. How well service will contribute to the continuation of Campus life in the dynamics of long-term competition (Aprillia \& Magdalena, 2018).

The results of several researchers in the field of digital promotion concluded that virtual campus roaming applications are useful to help and facilitate the community especially prospective new students to get to know the Campus environment in more detail. It is also a digital promotion media to improve Campus attractiveness (Anwar, 2018; Falani et al., 2016).

Taking into account the urgency, it is necessary to have an application that can provide the experience of prospective new students to colleagues from within and outside the country as if they can walk in the Jatim National Development University "Veteran" with virtual mode. Thus, this study aims to design and build a Virtual Campus Exploration Application (Jejakatua) as a Promotional Media in the Millennial Era at the UPN "Veteran" Jatim, by utilizing customized panoramic images so that users can experience the UPN "Veteran" Jatim online and feels realistic. A virtual tour is used to assist the user to view the panorama in real-time, feeling like actually being there. It is useful for universities to provide information that will enhance the journey on the Internet and show close images of the campus environment in a better, clearer, and more interactive way (Abu Hashim et al., 2007).

\section{Literature Review \\ Virtual campus}

Virtual tours provide information through multimedia that can impress users, users navigate locations and experience them in real-time (Bessey, 2013; Falani et al., 2016). Tour characteristics represent the image of the place of the object, accurate layout, available facilities, interactivity, and the ability to navigate freely in the virtual. Successful virtual tours are those that can provide experiences such as visiting the actual location can be achieved by using characteristics that realistically represent places that will be actualized to describe the virtual environment that feels real and almost indistinguishable (Maines \& Tang, 2015).

Virtual campus tours or later called virtual campus roaming are effective ways to show public facilities of a location. Several campuses in Indonesia already have a virtual campus roaming form on the Campus website. As if the Campus wants to show visitors to the Campus web and in particular to prospective students related to the potential of both national and international facilities at each campus. Roaming techniques Virtual campuses typically use panoramas 3600 so that this technology places the user in the image and allows users to increase situational awareness and significantly increase viewing power, capture and analyze virtual data (Nata, 2017).

\section{KRPano Viewer}

Panorama is a collection of several images that are interrelated to produce a wider viewpoint and at the same time become one type of photographic technique that displays the results or output of images or photos that are wider because of ordinary images or photos (Falani 2016). Krpano viewer is a small and very flexible high-performance viewer for all types of panoramic images and interactive virtual tours. The viewer is available as a Flash and HTML5 application. The viewer is designed for use in the Browser on Desktop (Windows, Mac, Linux) and Phones / Tablets (iPhone, iPad, Android). (https://krpano.com). 


\section{Methods}

The research method used in developing this virtual tour guide application is Multimedia Development Life Cycle (MDLC). The MDLC method is a method for the development of the multimedia application. Virtual tour guide application is an application that can be classified as a multimedia application because it uses photos, images, audio, and even video as material/data address. The MDLC method has 6 stages, namely concept, design, material collection, assembly, testing, and distribution.

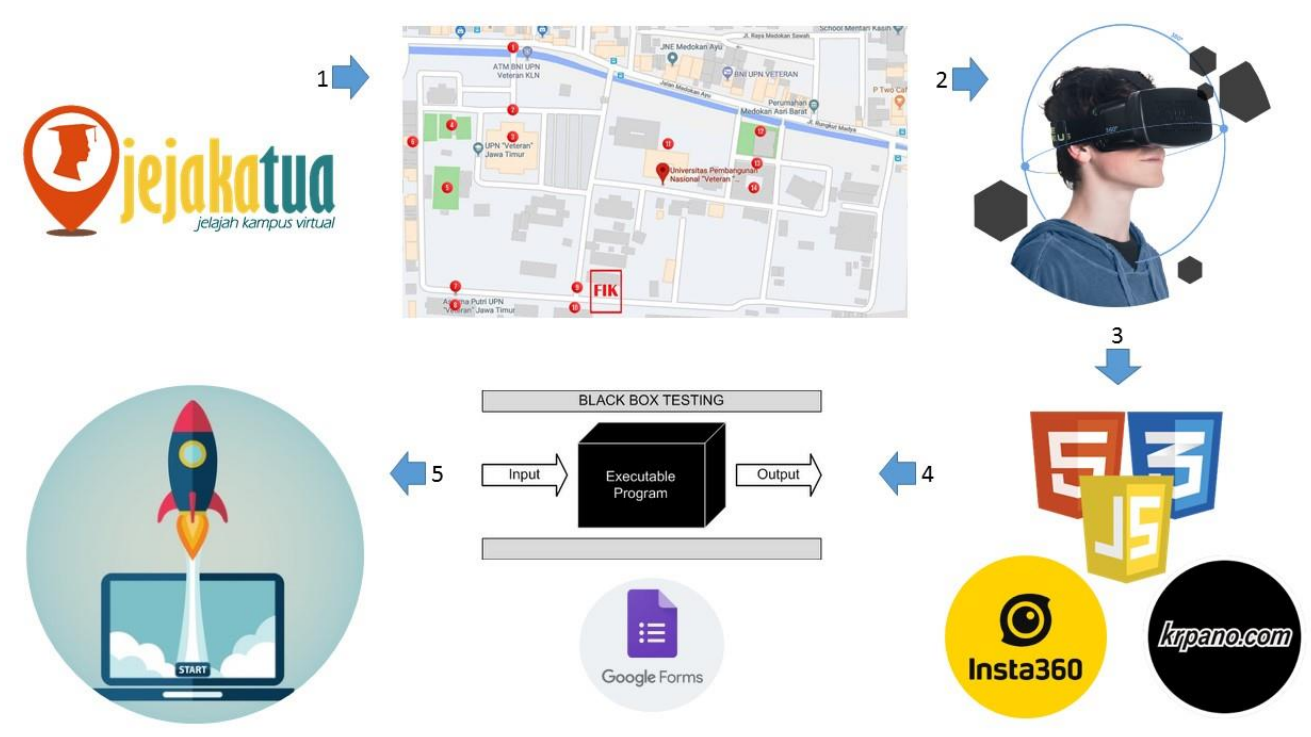

Figure 1. Method MDLC (Multimedia Development Life Cycle)

\section{Concept}

In this concept stage, the researcher determines the Jejakatua application user and the various tools that are in it, so at this stage, the researcher has determined that Jejakatua application users are all people in general and especially those who have an interest in East Java UPN "Veterans" such as examples of prospective students and prospective campus cooperation partners.

\section{Design}

The design or design phase is the stage of making specifications regarding program architecture, appearance, and material/material requirements for the program. Thus, the researcher makes a storyboard of the Jejakatua application to describe each procedure by including user activity.

\section{Content material}

The content stage is the stage of collecting materials that are following the needs being worked on. So, the researchers at this stage prepared the materials to be included in the Jejakatua application, including photographs of the UPN Veteran Jatim building, photographs of classrooms, laboratory space, lecturer rooms, and all the rooms in detail in the UPN Veteran Jatim building.

\section{Assembling}

The assembly stage is the stage that brings together all the objects or materials that have been obtained, thus the researcher merges all the photos of the UPN Veteran Jatim building room to be integrated into the Jejakatua application. 


\section{Testing}

The testing stage is the testing stage after completing the assembly stage, so the researcher runs the JAKATUA application which is then the Jejakatua performance. At the test phase using the alpha test method.

\section{Distribution}

At this stage, the application will be stored in storage media. This stage can also be called the evaluation stage for developing finished products to make them better. The results of this evaluation will also be used as input for the next stage of concept on the product. So the researcher will test the acceptance of the application technology, using the TAM theory.

\section{Results and Discussion Results}

To produce a study with data from the right results, it takes a place that has conformity with the design of the application being built. The appropriate place was used as the object of research at the UPN Veteran Jatim using the multimedia development life cycle system development method with the auto photo-stitching technique.

\section{Panorama $360^{\circ}$}

In this paper the researcher will provide 3 samplings of panoramic photos from 60 panoramic photos that have been obtained using the auto photo-stitching technique, this sampling aims to show the results of the panoramic photos that have been obtained in carrying out the research.

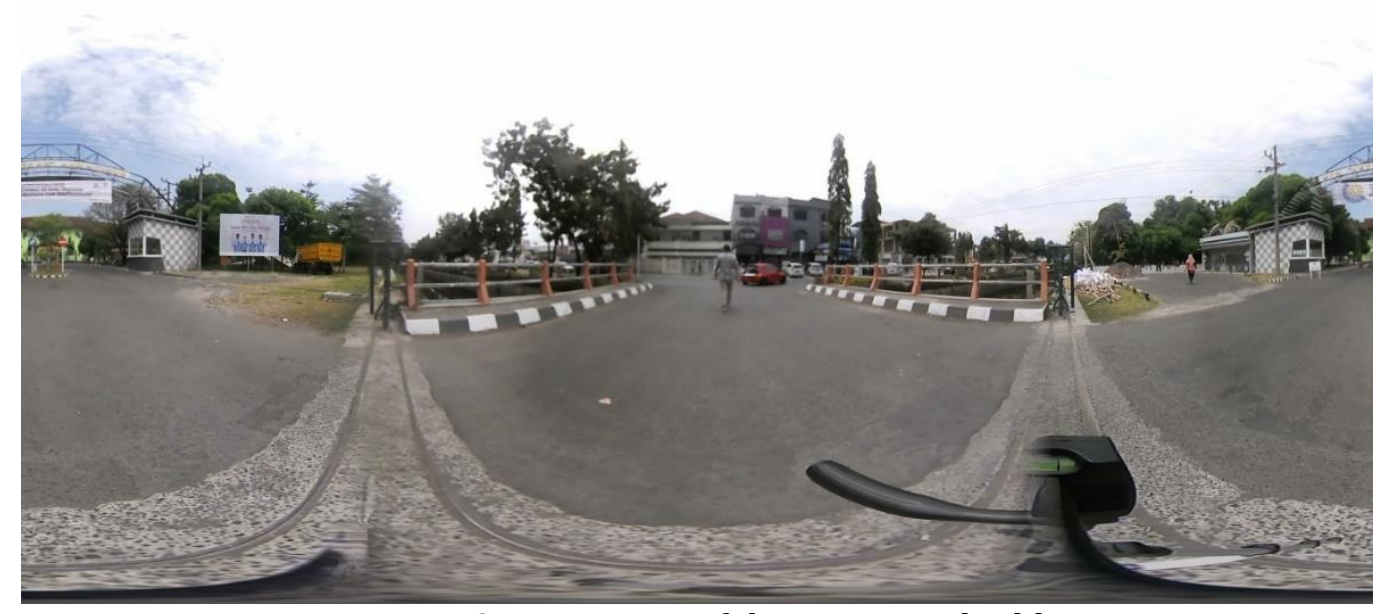

Figure 2. Front view of the giri pasca building 




Figure 3. Inside of the Giri Pasca building

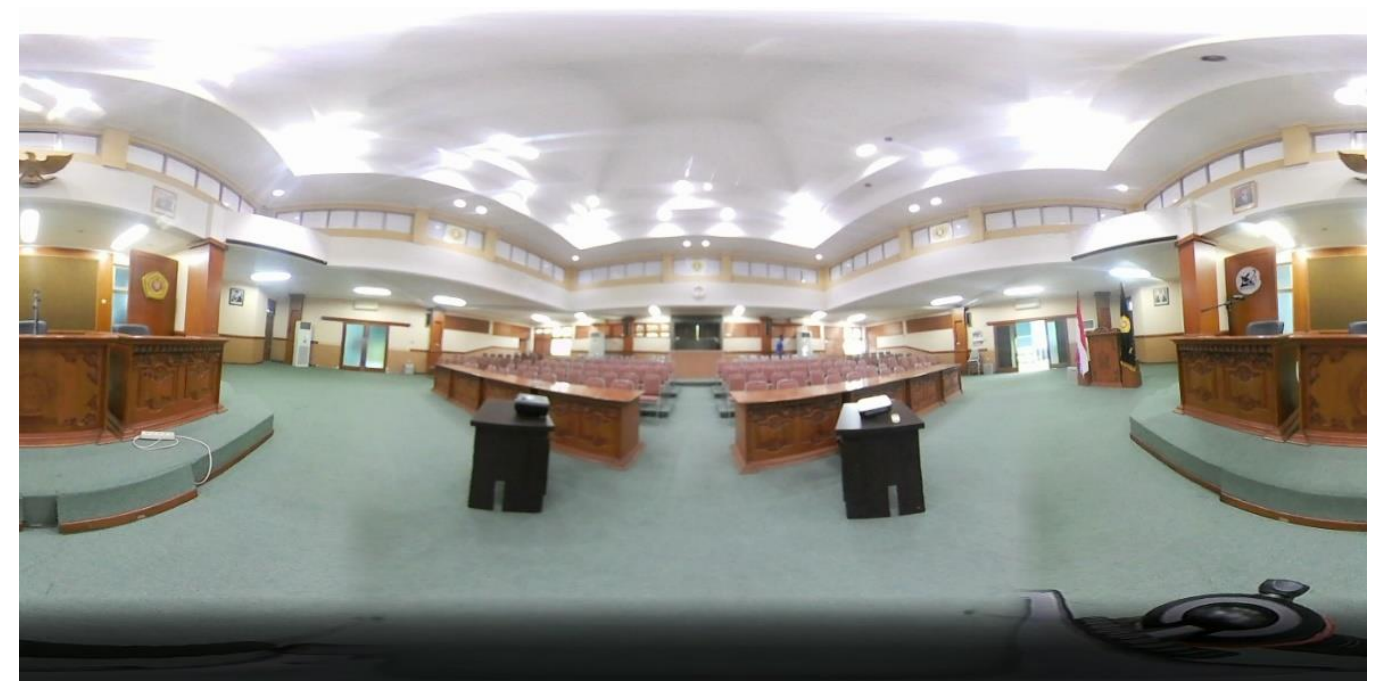

Figure 4. Inside of the Giri Pasca Room

\section{Jejakatua Apps}

There is a lot of navigation to direct to each building in UPN "Veteran" Jatim before finally entering the UPN Veteran Jatim building, then in this study will provide navigation sampling from the beginning to enter the main gate of UPN "Veteran" Jatim and then head to the UPN Veteran Jatim building. 


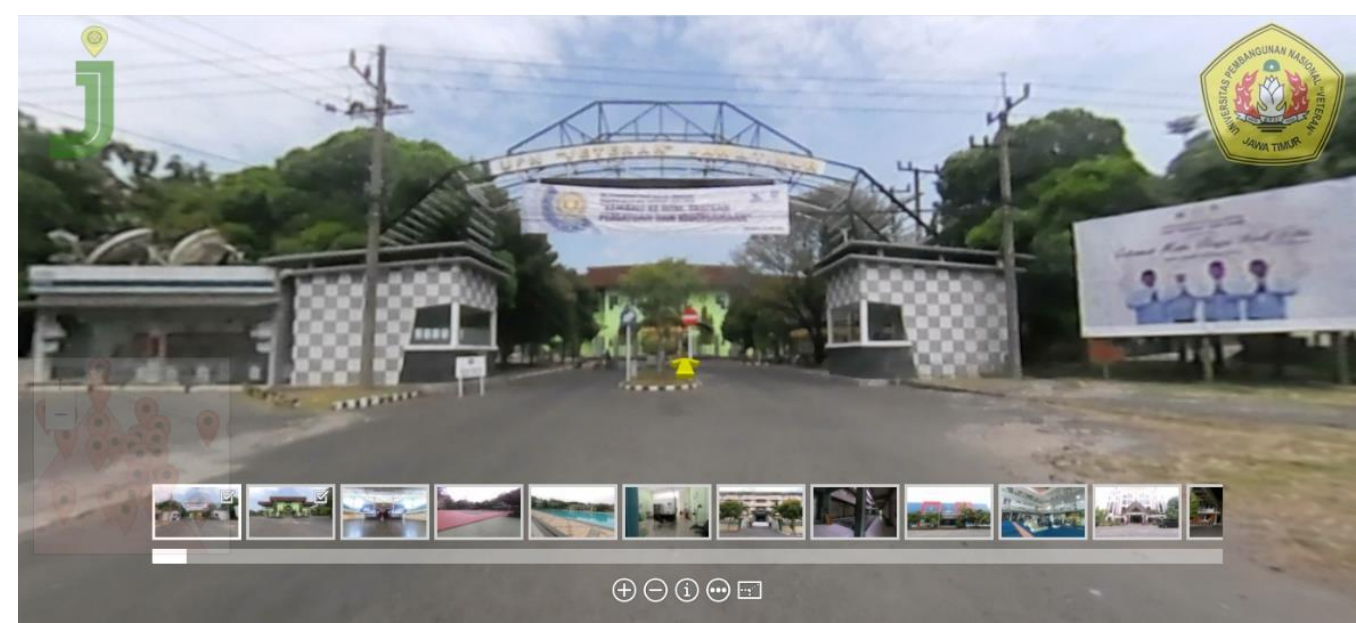

Figure 5. Front view of the UPN “Veteran” Jatim Gate

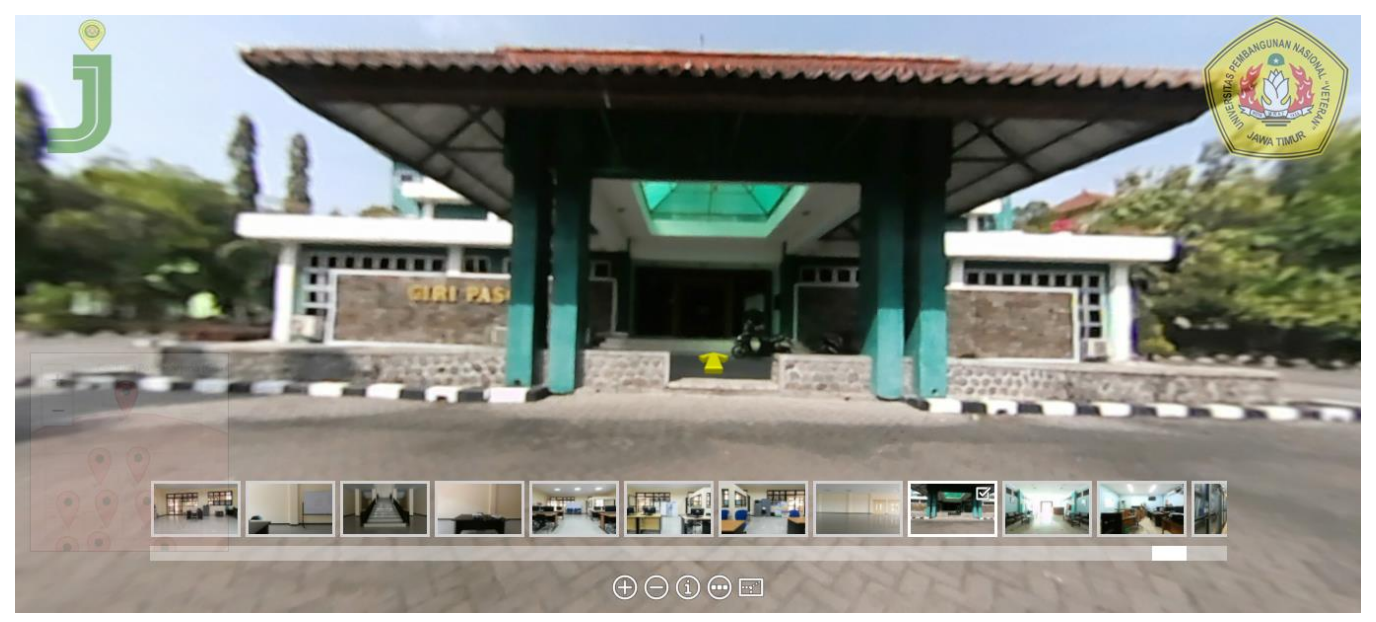

Figure 6. Front view of the Giri Pasca building

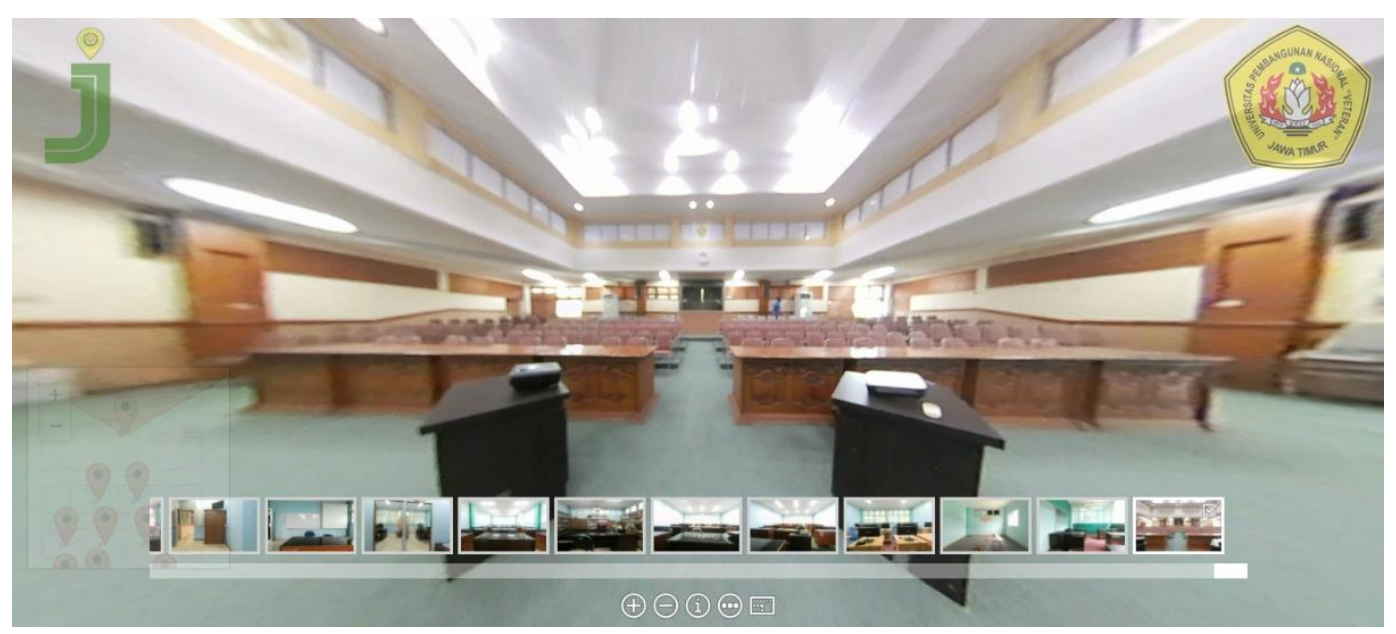

Figure 7. Inside View of the Giri Pasca Room 


\section{Conclusion}

In a conclusion, this research has achieved its objectives. The Jejakatua has been successfully developed using the auto photo-stitching technique.

1. This research has successfully applied auto-stitching techniques to the construction of Jejakatua at UPN "Veteran" East Java.

2. This research succeeded in producing a Virtual Campus Roaming (Jejakatua) application that can be used at UPN "Veteran" East Java.

3. This Jejakatua research resulted in information media support and digital promotion at UPN "Veteran" East Java.

\section{Acknowledgment}

Many thanks, the researchers conveyed to the UPN "Veteran" Jatim who supported and sponsored making this research workable.

\section{References}

Abu Hashim, A. H., Ibrahim, N., \& Hasnan, $\quad$ M. $\quad$ (2007). An interactive web-based virtual tour framework of UiTM Pahang.

Anwar, M. S. (2018). Rancang bangun aplikasi jelajah virtual panorama berbasis web pada Universitas PGRI Madiun. Journal of Computer and Information Technology, 2(1), 12-15. doi: 10.25273/doubleclick.v2i1.3203

Aprillia, A., \& Magdalena, N. (2018). Pengukuran kualitas layanan dalam bidang pendidikan tinggi. Jurnal Manajemen Maranatha, 18(1), 1-10. Doi: 10.28932/Jmm.V18i1.1092

Bessey, S. (2013). Virtual 3d Environments: Implementations of 3d Environments for Virtual Tours and Online Communication. 4

Falani, A. Z., Ramadan, H. A. S., \& Setiawan, E. (2016). Implementasi sistem virtual tour berbasis epanorama untuk pengenalan kampus Universitas Narotama Surabaya. Jurnal Insand Comtech, 1(1), 11.

Hendrayana, A. S. (2014). Pengaruh Kualitas Pelayanan Dan Nilai Pelanggan Terhadap Citra Serta Dampaknya Pada Loyalitas Mahasiswa. Jurnal Riset Manajemen (Image), 3(2), 1-10.

Maines, C., \& Tang, S. (2015). An application of game technology to virtual University Campus Tour and Interior Navigation. International Conference on Developments of E-Systems Engineering. doi: 10.1109/DeSE.2015.15

Nata, G. N. M. (2017). Aplikasi virtual tour guide sebagai promosi pariwisata Bali. Jurnal Sistem Dan Informatika, 11(2), 73-79. 